\title{
Identification and association of $R A C 1$ gene polymorphisms with mRNA and protein expression levels of Rac1 in solid organ (kidney, liver, heart) transplant recipients
}

\author{
JIALI ZHOU*, YANI LIU*, XIAOMEI LUO, RUFEI SHEN, CHUNXIAO YANG, TINGYU YANG and SHAOJUN SHI \\ Department of Pharmacy, Union Hospital, Tongji Medical College, Huazhong University of Science and Technology, \\ Wuhan, Hubei 430022, P.R. China
}

Received July 11, 2015; Accepted May 11, 2016

DOI: $10.3892 / \mathrm{mmr} .2016 .5383$

\begin{abstract}
The activation of Ras-related C3 botulinum toxin substrate 1 (Rac1) is critical in the renal, hepatic and cardiac diseases that lead to the requirement for transplantation, however, no investigations have been performed in Chinese populations to determine the association between $R A C l$ genotypes and the activation of Rac1. In the present study, 304 solid organ transplant recipients (SOTRs), consisting of 164 renal transplantations, 85 hepatic transplantations and 55 cardiac transplantations, and 332 Chinese healthy control subjects were recruited to investigate whether differences existed in the mRNA and protein expression levels of Rac1 in the different groups. Furthermore, the present study identified and investigated associations of the RACl (rs702482, rs10951982, rs702483 and rs6954996) genotypes with the mRNA expression levels of $R A C 1$, and the protein expression levels of total Rac1 and active Rac1-guanosine triphosphatase (GTP). It was identified that the healthy population had significantly
\end{abstract}

Correspondence to: Professor Shaojun Shi, Department of Pharmacy, Union Hospital, Tongji Medical College, Huazhong University of Science and Technology, 1277 Jiefang Avenue, Wuhan, Hubei 430022, P.R. China

E-mail: sjshicn@163.com

*Contributed equally

Abbreviations: SOTRs, solid organ transplant recipients; Rac1, Ras-related C3 botulinum toxin substrate 1; Rac1-GTP, active guanosine triphosphatase-bound Ras-related C3 botulinum toxin substrate 1; GTPases, guanosine triphosphatases; ROS, reactive oxygen species; SNP, single nucleotide polymorphism; IBD, inflammatory bowel disease; DEN, diethylnitrosamine; OR, odds ratio; $\mathrm{CI}$, confidence interval

Key words: Ras-related C3 botulinum toxin substrate 1, gene polymorphisms, mRNA, active GTP-bound Ras-related C3 botulinum toxin substrate 1 , kidney transplant recipients, liver transplant recipients, heart transplant recipients, Chinese healthy subjects higher levels of Rac1 and Rac1-GTP, compared with the kidney, liver and heart transplantation populations $(\mathrm{P}<0.001$ for all comparisons). Significant associations $(\mathrm{P}<0.05)$ were observed between the RACl genotypes and the expression levels of mRNA, Rac1 and Rac1-GTP. However, the changes in the mRNA expression levels of RACl with genotypes were different from those of the proteins. The results of the present study represent the first, to the best of our knowledge, to report that Rac1 and Rac1-GTP proteins can be downregulated in SOTRs, and that RACl genetic polymorphisms can potentially affect the mRNA expression of $R A C 1$, and the protein expression of Rac1 and Rac1-GTP. These results provide a foundation for further functional investigations to determine the biological and molecular functions of the RACl gene in SOTRs.

\section{Introduction}

The Ras-related C3 botulinum toxin substrate 1 (Rac1) protein, encoded by the $R A C l$ gene, is a $21 \mathrm{kDa}$ member of the Rho family of small guanosine triphosphatases (GTPases), and can cycle between an inactive guanosine diphosphate-bound state and an active GTP-bound (Rac1-GTP) state under the regulation of guanine nucleotide exchange factors (1). In its active GTP-bound state, Rac1 binds specifically to the p21-binding domain of $\mathrm{p} 21$-activated protein kinase to control downstream signaling cascades $(2,3)$. Rac1, as with other small GTPases, depends on the active GTP-bound state and is important in regulating several cellular processes, including cell-cell adhesion and epithelial-mesenchymal transition (4), meiosis and mitosis (5), cell Ras-mediated transformation (6), spreading and membrane ruffling (7), B-cell development and signaling (8), cross-talk with oncogenes (9) and reactive oxygen species (ROS) production $(10,11)$. In addition, Rac1 is known as a key regulator of a broad spectrum of transcription factors, including nuclear factor- $\kappa \mathrm{B}$, activating transcription factor 2, c-Jun and small mothers against decapentaplegic proteins (12-14).

The human $R A C 1$ gene is located on chromosome $7 \mathrm{p} 22$ and its structure has been described in full by Matos et al (15). Single nucleotide polymorphisms (SNPs) are the most common form of genetic polymorphism and account for $>90 \%$ 
of genetic variations (16). It is known that certain genetic variations can alter gene transcription and mRNA expression, which may transform the activity of proteins. The majority of these proteins are enzymes involved in several pathways and can alter susceptibility to diseases and drugs $(6,17-19)$. There are 2,061 SNPs in the human RACl gene, which have been found and named in the National Center for Biotechnology Information database (http://www.ncbi.nlm.nih.gov/snp). It has been reported that the $R A C 1$ gene SNP, rs10951982 (G/A), is significantly associated with ulcerative colitis (17), and a previous study revealed that $\mathrm{rs} 836478(\mathrm{C} / \mathrm{T})$ and $\mathrm{rs} 10951982$ (G/A) SNPs in the RACl gene are associated with higher levels of biomarkers, including interleukin 6 , metalloproteinase- 9 and plasminogen activator inhibitor-1, which may be connected with the development and progression of hypertension (18). It has also been suggested that polymorphisms of the RACl gene represent a possible additional mechanism contributing to inter-individual differences in the therapeutic effect of thiopurine drugs (19), which are widely used in the treatment of inflammatory bowel diseases (IBDs) (20), or as immunosuppressive agents in organ transplantation (21). RACl genetic polymorphisms have been reported to be involved in the development of IBDs, including ulcerative colitis and Crohn's disease $(17,22)$.

Epidemiological studies have consistently shown that several diseases in the kidney, liver and heart are associated with levels of Racl (23-27). In the kidney, it has been reported that Racl activation is associated with podocyte foot process effacement, leading to an increase in glomerular permeability and proteinuria $(23,24)$. The increased expression of Rac1-GTP has been shown in the glomeruli of rats with podocyte-specific overexpression of angiotensin II type I receptor, a model of effaced foot processes, podocyte depletion and focal segmental glomerular sclerosis (FSGS) $(28,29)$. In the liver, it has been found that a reduction in Rac1 activation reduced diethylnitrosamine (DEN)-induced formation of liver tumors, and that Racl can affect the basal and DEN-induced expression of metabolic liver enzymes (27). In the heart, it has been reported that Rac1 may be associated with the development of cardiovascular damage and salt-sensitive hypertension, which may be due to a crosstalk effect between Rac1 and mineralocorticoid receptor activation independent of aldosterone (18-31). Therefore, patients with kidney, liver or heart transplantats were included in the present study as case groups. It is reasonable to suggest that polymorphisms of the $R A C l$ gene may be implicated in organ transplantation treated with thiopurine drugs, including azathioprine, 6-thioguanine and 6-mercaptopurine. However, the associations of $R A C 1$ gene polymorphisms with the mRNA expression of $R A C 1$, and the protein expression levels of total Racl and Rac1-GTP have not been investigated. In addition, no investigations have been performed to compare patients treated with kidney, liver or heart transplantation and healthy populations to examine differences in $R A C 1$ genotyping and the expression levels of $R A C l \mathrm{mRNA}$ and the Racl protein it encodese in the population groups.

In our previously reported studies $(32,33)$, eight SNPs in the human $R A C l$ gene were examined, and no significant differences in genotype or allele frequencies were found between healthy controls and renal transplant patients.
Furthermore, four tag-SNPs (rs702482, rs10951982, rs702483, and rs6954996) were identified in the previous studies. In the present study, healthy control subjects and patients with kidney, liver or heart transplantation were recruited, and the genotyping and identification of four tag-SNPs (rs702482, rs10951982, rs702483, and rs6954996) in the RACl gene were performed. In addition, the expression levels of mRNA, and the protein levels of the total Racl and Rac1-GTP encoded by the $R A C l$ gene, were investigated in all the recruited subjects.

The aim of the present study was to investigate whether differences exist in the mRNA expression levels of $R A C 1$, and in the expression of proteins encoded by the $R A C 1$ gene in the different population subgroups. Particular emphasis was focussed on the associations between the RACl genotypes and the expression levels of the mRNA and proteins of Rac1.

\section{Materials and methods}

Subjects. A total of 304 solid organ transplant recipients (SOTRs), consisting of 164 kidney transplantations, 85 liver transplantations and 55 heart transplantations, who were receiving azathioprine and cyclosporine immunosuppressant treatment, were recruited between March and May 2014 from the Department of Organ Transplantation Center of Union Hospital and Tongji Hospital, Tongji Medical College, Huazhong University of Science and Technology (Wuhan, China). All donor organs (kidney, liver and heart) were retrieved from the Accident and Emergency Department and intensive care units of the Union Hospital (Wuhan, China) and Tongji Hospital (Wuhan, China). Donor eligibility screening and assessment did not reveal any contraindications to transplantation, and the patient's family agreed to organ donation. In addition, a total of 332 ethnically and geographically matched healthy Chinese Han subjects were enrolled at Union Hospital (Wuhan, China) during the same period of time. All subjects enrolled in the present study met the following criteria: i) Body mass index between 18.5 and $24.9 \mathrm{~kg} / \mathrm{m}^{2}$; ii) age range between 20 and 60 years; iii) subjects in good health, as determined by complete physical examination, 12-lead electrocardiograms, chest X-ray, routine laboratory assessments, including routine hematology, blood chemistry and urine analyses, and negative pregnancy test results. In the SOTRs, the clinical data regarding the dose and duration of immunosuppressant administration, adverse drug reactions and laboratory data were assessed by screening of the patients' medical records. The study protocol was approved by the independent ethics committee of Tongji Medical College, Huazhong University of Science and Technology [Wuhan, China; approval no. (2012)S019]. All associated procedures were performed in accordance with the principles of the Declaration of Helsinki. All subjects were informed of the investigational nature of the study and signed informed consent prior to any screening procedure.

RNA and DNA extraction. Blood samples $(\sim 2 \mathrm{ml})$ were collected from the forearm vein into EDTA-treated Vacutainer tubes. Then $250 \mu$ l EDTA-treated blood was transferred into a clean tube and mixed with $750 \mu 1$ TRIzol for the RNA extraction. The remaining blood sample was centrifuged at $1,000 \mathrm{xg}$ for $10 \mathrm{~min}$ at $4^{\circ} \mathrm{C}$ to separate plasma and white blood cells for the measurement of Racl and Rac1-GTP levels and DNA 
Table I. Primer sequences for genotyping Ras-related C3 botulinum toxin substrate 1 SNPs.

\begin{tabular}{lcccc}
\hline dbSNP ID & Mutation & Area & Location & Primer \\
\hline rs702482 & T>A & Intron 1 & Chr7.6420199 & F: 5'-AAAAGTTTGGAGTTGGGCTAAGT-3' \\
rs10951982 & G>A & Intron 1 & Chr7.6422556 & F: 5'-ATGGCAAAACCCTGTCTCTACTG-3' \\
rs702483 & & & R: 5-GAAACGAACATGAGTCGGCTG-3' \\
rs6954996 & G & & Chr7.6426941 & F: 5'-TCCTGGAGAATATATCCCTACTGTG-3' \\
& G & & R:5'-GCCTCAGTCTCCCAAAGTGC-3' \\
& & Intron 4 & Chr7.6441258 & F: 5'-CAGTGGAGATAATAGCGGCAGAC-3' \\
& & & R:5'-TCCTTCACCTAAATCACACCCAG-3'
\end{tabular}

SNP, single nucleotide polymorphism; F, forward; R, reverse.

extraction, respectively. Total RNA extraction and isolation from the TRIzol-treated whole blood samples were performed, according to standard procedures. The genomic DNA was extracted according to the manufacturer's protocol. Total RNA and DNA were quantified using a Nanodrop 1000 spectrophotometer (Thermo Fisher Scientific, Inc., Wilmington, DE, USA). The extracted total RNA and genomic DNA samples were stored at $-80^{\circ} \mathrm{C}$ until processing for further analysis.

Genotyping and sequencing. Genotyping was performed using a total volume of $10 \mu \mathrm{l}$, containing $5 \mu \mathrm{l}$ TaqMan ${ }^{\circledR}$ Genotyping Master Mix (Life Technologies Grand Island, NY, USA), $1 \mu 1$ TaqMan ${ }^{\circledR}$ SNP Genotyping Assay (Life Technologies), $2 \mu \mathrm{l}$ extracted genomic DNA and $2 \mu \mathrm{l}$ deionized water. The sequences of the primers for the four tag-SNPs are presented in Table I.

The polymerase chain reaction (PCR) cycling conditions were as follows: Initial denaturation at $95^{\circ} \mathrm{C}$ for $4 \mathrm{~min}$, followed by 40 cycles of denaturation at $94^{\circ} \mathrm{C}$ for $30 \mathrm{sec}$, annealing at $60^{\circ} \mathrm{C}$ for $1 \mathrm{~min}$, extension at $72^{\circ} \mathrm{C}$ for $30 \mathrm{sec}$ and a final extension step at $72^{\circ} \mathrm{C}$ for $10 \mathrm{~min}$. The amplifications were performed using a 7900HT Fast Real-Time PCR system (Applied Biosystems; Thermo Fisher Scientific, Inc.). Data acquisition and analyses were performed using SDS v2.3 Allelic Discrimination software (Applied Biosystems; Thermo Fisher Scientific, Inc.). Direct sequencing was performed to confirm the genotyping accuracy. In total, five cases of each genotype were detected using a BigDye Terminator v3.1 cycle sequencing kit and an ABI 3130 genetic analyzer (Applied Biosystems; Thermo Fisher Scientific, Inc.).

Reverse transcription-quantitative PCR (RT-qPCR) and cDNA sequencing. Total RNA was transcribed into cDNA using a PrimeScript $^{\mathrm{TM}}$ RT reagent kit with gDNA Eraser (Takara Bio, Inc., Tokyo, Japan), according to the manufacturer's protocol. RT-qPCR analyses were performed in triplicate, using $\beta$-actin for normalization. SYBR ${ }^{\circledR}$ Premix Ex Taq ${ }^{\mathrm{TM}}$ II (Tli RNaseH Plus; Takara Bio, Inc.) was for the amplification of cDNA. The sequences of the primers used for RT-qPCR were designed and synthesized by Takara Bio., Inc., as follows: $\beta$-actin, forward 5'-TGGCACCCAGCACAATGAA-3' and reverse 5'-CTAAGT CATAGTCCGCCTAGAAGCA-3'; $R A C 1$, forward 5'-GCG
TTGCCATTGAACTCACC-3' and reverse 5'-GAGCTGCTA CGCTCACTCCATTAC-3'. qPCR for RNA expression was performed on a 7900HT Fast Real-Time PCR system (Applied Biosystems; Thermo Fisher Scientific, Inc.) using a total volume of $10 \mu \mathrm{l}$, containing $5 \mu \mathrm{l} \mathrm{SYBR}{ }^{\mathrm{R}}$ Premix Ex $\operatorname{Taq}^{\mathrm{TM}}(2 \mathrm{X}$; Takara Bio, Inc.), $0.2 \mu \mathrm{l}$ ROX reference dye (50X; Takara Bio., Inc.), $3.4 \mu \mathrm{l}$ sterile water (Takara Bio., Inc.), $0.2 \mu \mathrm{l}$ forward primer, $0.2 \mu \mathrm{l}$ reverse primer and $1 \mu \mathrm{l}$ cDNA. The RT-qPCR conditions comprised a holding stage $\left(95^{\circ} \mathrm{C}\right.$ for $\left.30 \mathrm{sec}\right)$, cycling stage $\left(95^{\circ} \mathrm{C}\right.$ for $5 \mathrm{sec}$ and 40 cycles at $60^{\circ} \mathrm{C}$ for $\left.30 \mathrm{sec}\right)$ and melt curve stage $\left(95^{\circ} \mathrm{C}\right.$ for $15 \mathrm{sec}, 60^{\circ} \mathrm{C}$ for $1 \mathrm{~min}$ and $95^{\circ} \mathrm{C}$ for $15 \mathrm{sec}$ ). The amplifications were performed using the $7900 \mathrm{HT}$ Fast Real-Time PCR system (Applied Biosystems; Thermo Fisher Scientific, Inc.).

Enzyme-linked immunosorbent assay (ELISA). The protein levels of total Rac1 and Rac1-GTP were evaluated in the serum samples from all participants using the Rac1/Rac1-GTP ELISA kit (Elabscience Biotechnology Co., Ltd., Wuhan, China), according to the manufacturer's protocol. According to the results of the preliminary experiment, $10 \mathrm{X}$ dilutions of the serum samples were used for the assaying of Rac1, and $5 \mathrm{X}$ dilutions of the serum samples were used for the assaying of Rac1-GTP. The assays of the protein levels of Rac1 and Rac1-GTP were performed in triplicate, and a separate standard curve was established for each assessment on different days or using ELISA kits with different batch numbers.

Statistical analysis. Statistical analyses were performed using SPSS 17.0 software (SPSS, Inc., Chicago, IL, USA), and $\mathrm{P}<0.05$ was considered to indicate a statistically significant difference for all analyses. The allele and genotype frequencies were calculated by direct counting and were assessed tested for significant deviation from Hardy-Weinberg equilibrium using a goodness-of-fit $\chi^{2}$ test. Linkage disequilibrium analysis between the different pairs of SNPs was performed using the Haploview version 4.2 software package (Broad Institute of Massachusetts Institute of Technology and Harvard University, Cambridge, MA, USA). Skewed data are presented as the mean \pm standard deviation of log-transformed values in text and box-and-whisker plots in figures. The distributions of characteristics between cases 
Table II. Demographic characteristics and laboratory findings.

\begin{tabular}{|c|c|c|c|c|c|}
\hline \multirow[b]{2}{*}{ Characteristic } & \multicolumn{3}{|c|}{ Cases } & \multirow[b]{2}{*}{$\begin{array}{l}\text { Healthy control } \\
\qquad(n=332)\end{array}$} & \multirow[b]{2}{*}{ P-value } \\
\hline & $\begin{array}{l}\text { Renal transplantation } \\
\qquad(\mathrm{n}=164)\end{array}$ & $\begin{array}{l}\text { Liver transplantation } \\
\qquad(\mathrm{n}=85)\end{array}$ & $\begin{array}{l}\text { Heart transplantation } \\
\qquad(\mathrm{n}=55)\end{array}$ & & \\
\hline Age (years, mean \pm SD) & $43.1 \pm 11.2$ & $45.0 \pm 12.0$ & $43.0 \pm 12.0$ & $45.0 \pm 12.3$ & $0.782^{\mathrm{a}}$ \\
\hline Gender & & & & & $0.898^{\mathrm{b}}$ \\
\hline Male; n (\%) & $104(63.41)$ & $55(64.71)$ & $34(61.82)$ & $211(63.55)$ & \\
\hline Female; n (\%) & $60(36.59)$ & $30(35.29)$ & $21(38.18)$ & $121(36.45)$ & \\
\hline rs702482; n (\%) & & & & & $0.181^{\mathrm{c}}$ \\
\hline A & $143(43.60)$ & $71(41.76)$ & $36(32.73)$ & $290(43.67)$ & \\
\hline $\mathrm{T}$ & $185(56.40)$ & $99(58.24)$ & $74(67.27)$ & $374(56.33)$ & \\
\hline AA & $40(24.39)$ & $16(18.82)$ & $3(5.45)$ & 77 (23.19) & $0.082^{\mathrm{d}}$ \\
\hline AT & $63(38.41)$ & $39(45.88)$ & $30(54.55)$ & $136(40.96)$ & \\
\hline $\mathrm{TT}$ & $61(37.20)$ & $30(35.29)$ & $22(40.00)$ & $119(35.84)$ & \\
\hline rs10951982; n (\%) & & & & & $0.079^{\mathrm{c}}$ \\
\hline A & $80(24.39)$ & $54(31.76)$ & $20(18.18)$ & $168(25.30)$ & \\
\hline $\mathrm{G}$ & $248(75.61)$ & $116(68.24)$ & $90(81.82)$ & $496(74.70)$ & \\
\hline AA & 17 (10.37) & $17(20.00)$ & $3(5.45)$ & $44(13.25)$ & $0.218^{\mathrm{d}}$ \\
\hline $\mathrm{AG}$ & $46(28.05)$ & $20(23.53)$ & $14(25.45)$ & $80(24.10)$ & \\
\hline GG & $101(61.58)$ & $48(56.47)$ & 38 (69.09) & $208(62.65)$ & \\
\hline rs702483; n (\%) & & & & & $0.250^{\mathrm{c}}$ \\
\hline A & $279(85.06)$ & $151(88.82)$ & $89(80.91)$ & $554(83.43)$ & \\
\hline G & 49 (14.94) & 19 (11.18) & $21(19.09)$ & $110(16.57)$ & \\
\hline GG & $4(2.44)$ & $2(2.35)$ & $2(3.64)$ & $17(5.12)$ & $0.374^{\mathrm{d}}$ \\
\hline $\mathrm{AG}$ & $41(25.00)$ & $15(17.65)$ & 17 (30.91) & 76 (22.89) & \\
\hline AA & $119(72.56)$ & $68(80.00)$ & $36(65.45)$ & 239 (71.99) & \\
\hline rs6954996; n (\%) & & & & & $0.772^{\mathrm{c}}$ \\
\hline A & 49 (14.94) & $24(14.12)$ & $20(18.18)$ & $108(16.27)$ & \\
\hline $\mathrm{G}$ & $279(85.06)$ & $146(85.88)$ & $90(81.82)$ & $556(83.73)$ & \\
\hline AA & $5(3.05)$ & $4(4.71)$ & $3(5.45)$ & $17(5.12)$ & $0.894^{\mathrm{d}}$ \\
\hline $\mathrm{AG}$ & 39 (23.78) & $16(18.82)$ & $14(25.45)$ & $74(22.29)$ & \\
\hline GG & $120(73.17)$ & $65(76.47)$ & 38 (69.09) & $241(72.59)$ & \\
\hline
\end{tabular}

${ }^{a}$ Differences in age distribution, determined by $\chi^{2} .{ }^{\mathrm{b}}$ Gender differences determined by $\chi^{2}$. ${ }^{\mathrm{c}}$ Differences in allele distribution, determined by $\chi^{2}$. ${ }^{\mathrm{d}}$ Differences in genotype distribution, determined by $\chi^{2}$.

and controls were evaluated using a $\chi^{2}$ test for categorical variables or using one-way analysis of variance (ANOVA) followed by Tukey's post-hoc test for continuous variables. To analyze the effects of the four specific tag-SNPs on the formation and development of kidney, liver or heart failure, risk analysis modelling was used to calculate the odds ratios (ORs) and 95\% confidence intervals (CIs).

\section{Results}

Demographic characteristics and laboratory results. The demographic characteristics of the subjects involved in the present study are summarized in Table II. The characteristics of the patients were based on data collected retrospectively from medical records. No significant differences in age stratification or gender ratio were found in either group $(\mathrm{P}>0.05)$.
Genotyping and identification of RACl gene polymorphisms. The four tag-SNPs in RACl gene were successfully genotyped using TaqMan technology. No pairwise linkage disequilibrium was found in the four tag-SNPs $\left(r^{2}<0.3\right)$. The allele and genotype frequencies were calculated by direct counting and goodness-of-fit $\chi^{2}$ tests, the results of which showed that there were no significant differences in any of the SNPs among the transplant and control groups ( $\mathrm{P}>0.05$; Table II).

For the analysis of individual SNPs, dominant model (heterozygotes plus minor allele homozygotes vs. major allele homozygotes), recessive model (minor allele homozygotes vs. major allele homozygotes plus heterozygotes) and over-dominant model (minor allele homozygotes plus major allele homozygotes vs. heterozygotes) were used in the present study (Table III). No significant differences in the genotype or allele frequencies of rs10951982, rs702483 and 
Table III. Genotype distribution of the Ras-related C3 botulinum toxin substrate 1 gene in transplantation cases and healthy controls.

\begin{tabular}{|c|c|c|c|c|c|c|}
\hline \multirow[b]{2}{*}{ SNP } & \multicolumn{2}{|c|}{$\begin{array}{c}\text { Renal transplantation, vs. } \\
\text { healthy control }\end{array}$} & \multicolumn{2}{|c|}{$\begin{array}{l}\text { Liver transplantation, vs. } \\
\text { healthy control }\end{array}$} & \multicolumn{2}{|c|}{$\begin{array}{l}\text { Heart transplantation, vs. } \\
\text { healthy control }\end{array}$} \\
\hline & $\mathrm{P}$-value & OR $(95 \% \mathrm{CI})$ & P-value & OR $(95 \% \mathrm{CI})$ & P-value & OR $(95 \% \mathrm{CI})$ \\
\hline \multicolumn{7}{|l|}{ rs702482 } \\
\hline $\mathrm{TT}+\mathrm{AT}, \mathrm{vs} . \mathrm{AA}$ & 0.768 & $0.936(0.604,1.451)$ & 0.388 & $1.302(0.714,2.374)$ & 0.003 & $5.234(1.590,17.228)$ \\
\hline TT, vs. AA+AT & 0.768 & $1.060(0.719,1.563)$ & 0.925 & $0.976(0.593,1.607)$ & 0.553 & $1.193(0.665,2.140)$ \\
\hline AA+TT, vs. AT & 0.586 & $1.112(0.758,1.632)$ & 0.412 & $0.818(0.507,1.322)$ & 0.059 & $0.578(0.326,1.027)$ \\
\hline \multicolumn{7}{|l|}{ rs10951982 } \\
\hline $\mathrm{AA}+\mathrm{AG}$, vs. GG & 0.818 & $1.046(0.712,1.538)$ & 0.296 & $1.293(0.798,2.096)$ & 0.358 & $0.750(0.406,1.386)$ \\
\hline AA, vs. GG+AG & 0.357 & $0.757(0.418,1.371)$ & 0.116 & $1.636(0.881,3.039)$ & 0.101 & $0.378(0.113,1.262)$ \\
\hline $\mathrm{AA}+\mathrm{GG}, \mathrm{vs} . \mathrm{AG}$ & 0.341 & $0.814(0.533,1.244)$ & 0.913 & $1.032(0.589,1.808)$ & 0.828 & $0.930(0.482,1.793)$ \\
\hline \multicolumn{7}{|l|}{ rs702483 } \\
\hline $\mathrm{GG}+\mathrm{AG}$, vs. AA & 0.893 & $0.972(0.640,1.477)$ & 0.135 & $0.642(0.359,1.151)$ & 0.322 & $1.356(0.741,2.484)$ \\
\hline $\mathrm{GG}$, vs. AA+AG & 0.163 & $0.463(0.153,1.400)$ & 0.275 & $0.446(0.101,1.971)$ & 0.637 & $0.699(0.157,3.114)$ \\
\hline GG+AA, vs. AG & 0.603 & $0.891(0.576,1.378)$ & 0.296 & $1.385(0.750,2.559)$ & 0.197 & $0.664(0.355,1.242)$ \\
\hline \multicolumn{7}{|l|}{ rs6954996 } \\
\hline $\mathrm{AA}+\mathrm{AG}$, vs. GG & 0.891 & $0.971(0.637,1.480)$ & 0.470 & $0.815(0.467,1.421)$ & 0.592 & $1.185(0.637,2.204)$ \\
\hline AA, vs. GG+AG & 0.292 & $0.583(0.211,1.608)$ & 0.876 & $0.915(0.300,2.794)$ & 0.914 & $1.072(0.304,3.788)$ \\
\hline $\mathrm{AA}+\mathrm{GG}, \mathrm{vs} . \mathrm{AG}$ & 0.709 & $0.919(0.590,1.431)$ & 0.488 & $1.237(0.677,2.259)$ & 0.604 & $0.840(0.434,1.624)$ \\
\hline
\end{tabular}

SNP, single nucleotide polymorphism; OR, odds ratio; CI, confidence interval.

A

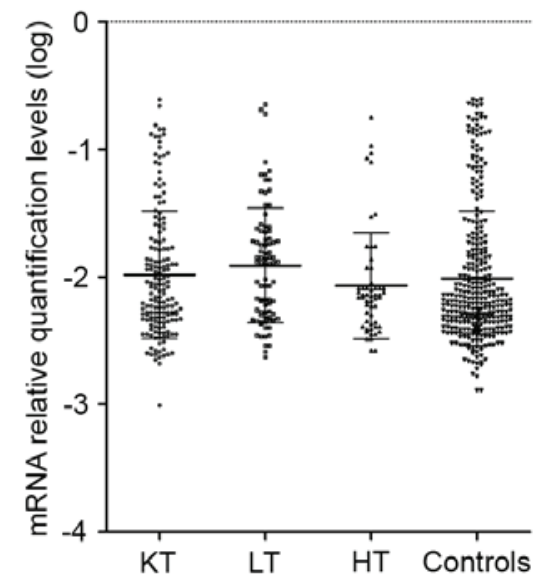

B

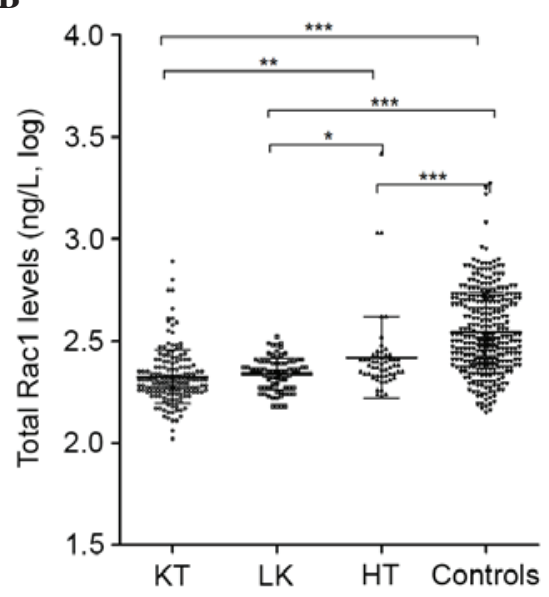

C

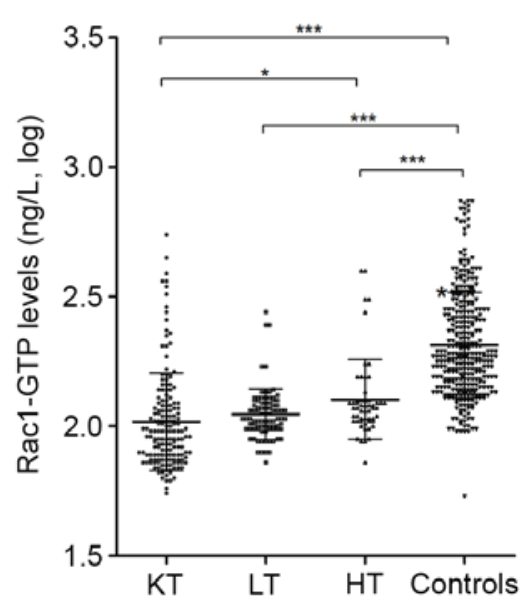

Figure 1. Expression levels of $R A C 1$ mRNA, total Rac1 and Rac1-GTP in transplant cases and healthy controls. (A) Relative mRNA levels of $R A C 1$. (B) Levels of total Rac1. (C) Levels of Rac1-GTP. For multiple comparisons, one-way analysis of variance following log-transformation, followed by Tukey's post-hoc test, was performed for each group. ${ }^{*} \mathrm{P}<0.05,{ }^{* *} \mathrm{P}<0.01$ and ${ }^{* * * *} \mathrm{P}<0.001$. Rac1, Ras-related C3 botulinum toxin substrate 1; Rac1-GTP, Rac1-guanosine triphosphatase; KT, kidney transplantation; LT, liver transplantation; HT, heart transplantation.

rs6954996 were observed between the transplant cases and healthy control $(\mathrm{P}>0.05)$. However, TT+AT in rs702482 was distributed differentially $(\mathrm{OR}=5.234 ; 95 \% \mathrm{CI}=1.590-17.228$; $\mathrm{P}=0.003$ ), compared with AA in rs702482 between the heart transplantation cases and the healthy control.

Relative quantification of $m R N A$ levels. In order to investigate differences in the mRNA expression levels of $R A C l$ between the transplantation cases and healthy controls, the present study performed RT-qPCR analyses to measure the mRNA expression levels in all the recruited subjects. The $R A C l$ gene and the reference gene, $\beta$-actin, were all amplified fully and successfully under the final RT-qPCR reaction systems and conditions. The relative mRNA levels of $R A C l$ among groups were compared by one-way ANOVA following log-transformation, followed by Tukey's post-hoc test, however, no significant differences were found $(\mathrm{P}>0.05$; Fig. 1A). 
A

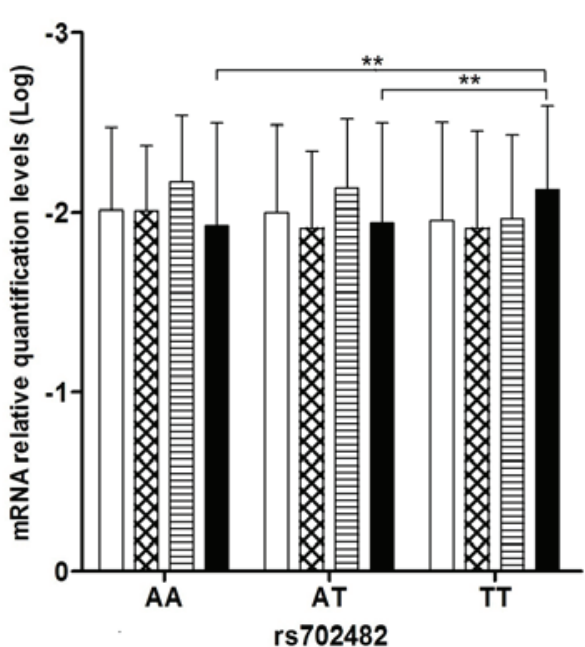

C

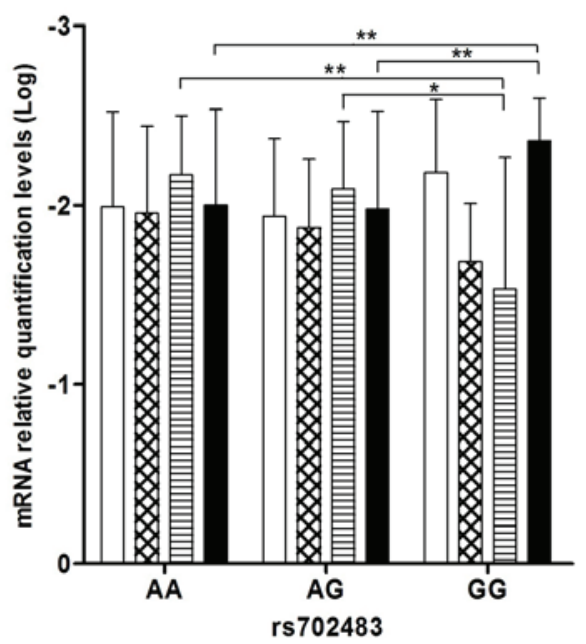

B
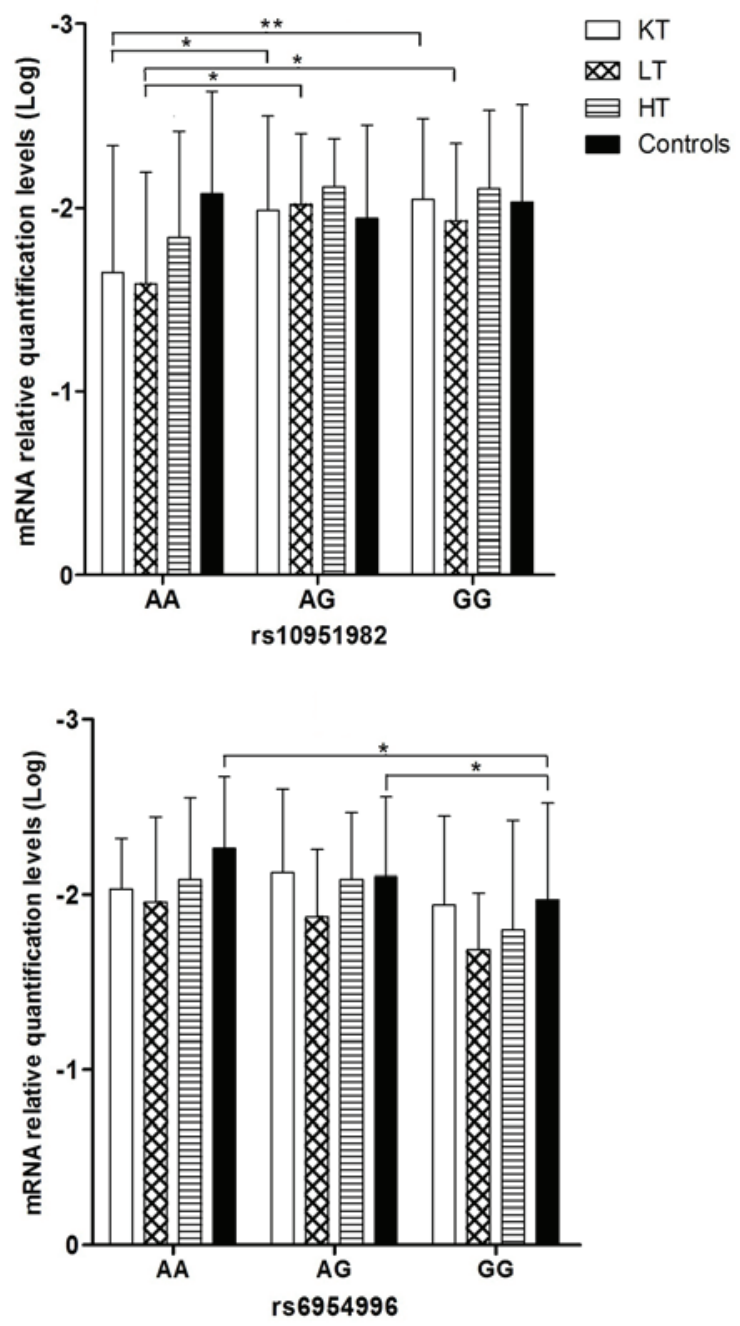

Figure 2. Association analysis of RAC1 genotypes with mRNA expression levels. (A) Association analysis of rs702482 genotypes with mRNA levels; (B) association analysis of rs10951982 genotypes with mRNA levels; (C) association analysis of rs702483 genotypes with mRNA levels; (D) association analysis of rs6954996 genotypes with mRNA levels. For multiple comparisons, one-way analysis of variance following log-transformation, followed by Tukey's post-hoc test, was performed for each group. ${ }^{*} \mathrm{P}<0.05$ and ${ }^{* *} \mathrm{P}<0.01$. Rac1, Ras-related C3 botulinum toxin substrate 1; KT, kidney transplantation; LT, liver transplantation; HT, heart transplantation.

Expression levels of total Racl and Racl-GTP. The protein levels of total Rac1 and Rac1-GTP among the groups were compared using one-way ANOVA following log-transformation, followed by Tukey's post-hoc test. As shown in Fig. 1B and C, the highest levels of total Racl and Rac1-GTP were found in the healthy control group $(2.54 \pm 0.20$ and $2.31 \pm 0.20 \mathrm{ng} / \mathrm{l}$, respectively), compared with those in the kidney transplant group $(2.32 \pm 0.13$ and $2.02 \pm 0.19 \mathrm{ng} / 1$, respectively), liver transplant group (2.34 \pm 0.08 and $2.05 \pm 0.10 \mathrm{ng} / \mathrm{l}$, respectively) and heart transplant group $(-2.42 \pm 0.20$ and $2.10 \pm 0.15 \mathrm{ng} / \mathrm{l}$, respectively; $\mathrm{P}<0.001$ for all comparisons). However, no significant differences $(\mathrm{P}>0.05)$ were found when the levels of total Rac1 and Rac1-GTP were compared among the three transplant groups.

Association between RACl genotypes and mRNA levels. The present study also investigated the association between the $R A C l$ genotype and relative mRNA levels in the examined populations, and significant differences were noted, as shown in Fig. 2. Significant associations $(\mathrm{P}<0.05)$ were observed between the rs702482, rs702483 and rs6954996 genotypes and the relative quantification levels of mRNA in the healthy control group. For rs702482, the relative mRNA levels were lowest in the TT genotype $(-2.12 \pm 0.47$; mean \pm standard deviation), compared with the AA genotype $(-1.93 \pm 0.57)$ and AT genotype $(-1.94 \pm 0.55)$, respectively $(\mathrm{P}<0.01)$. For rs702483, the relative mRNA levels were lowest in the GG genotype $(-2.35 \pm 0.24)$, compared with the AA genotype $(-2.00 \pm 0.53)$ and AG genotype $(-1.98 \pm 0.55)$, respectively $(\mathrm{P}<0.01)$. For rs6954996, the relative mRNA levels were highest in the GG genotype (-1.97 \pm 0.55$)$, compared with the AG genotype $(-2.10 \pm 0.46)$ and AA genotype $(-2.26 \pm 0.41)$, respectively $(\mathrm{P}<0.05)$. In the kidney transplant group the mRNA level was highest in the AA genotype (-1.65 \pm 0.69$)$, compared with the AG genotype $(-1.99 \pm 0.51 ; \mathrm{P}<0.05)$ and GG genotype $(-2.04 \pm 0.44, \mathrm{P}<0.01)$ of $\mathrm{rs} 10951982$, respectively. In the liver transplant group, the mRNA level was highest in the AA genotype (-1.58 \pm 0.61$)$, compared with the AG genotype $(-2.02 \pm 0.39)$ and GG genotype $(-1.93 \pm 0.42)$ of rs10951982 $(\mathrm{P}<0.05)$, respectively. Additionally, in the heart transplant group, the mRNA level was highest in GG genotype $(-1.53 \pm 0.73)$, compared with the AG genotype 
A

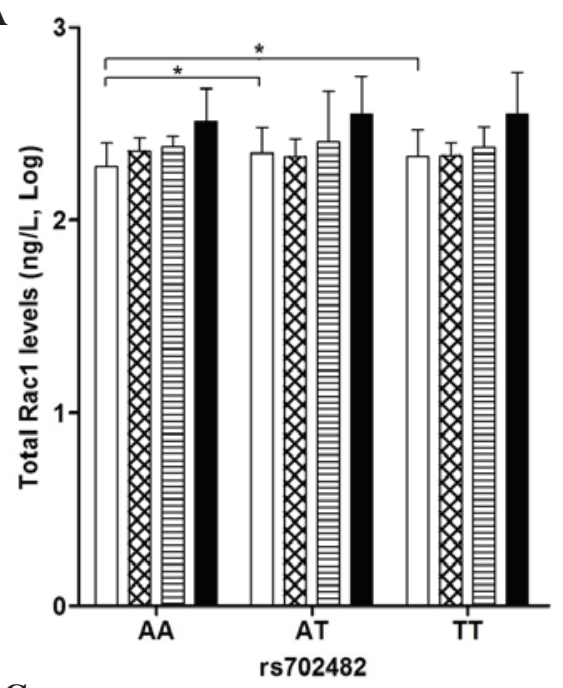

C

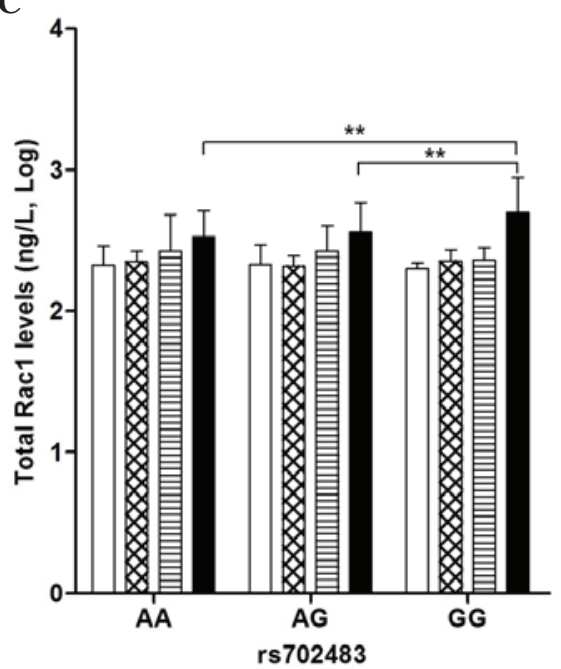

B

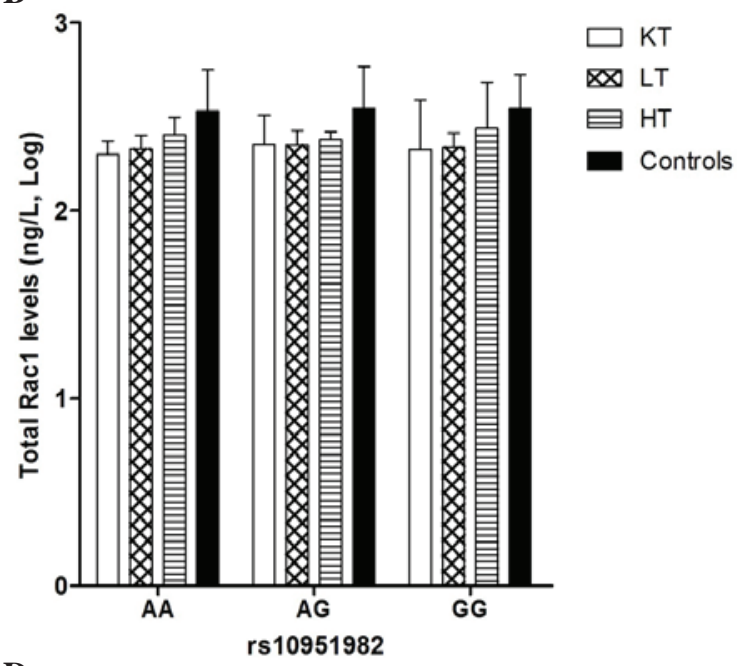

D

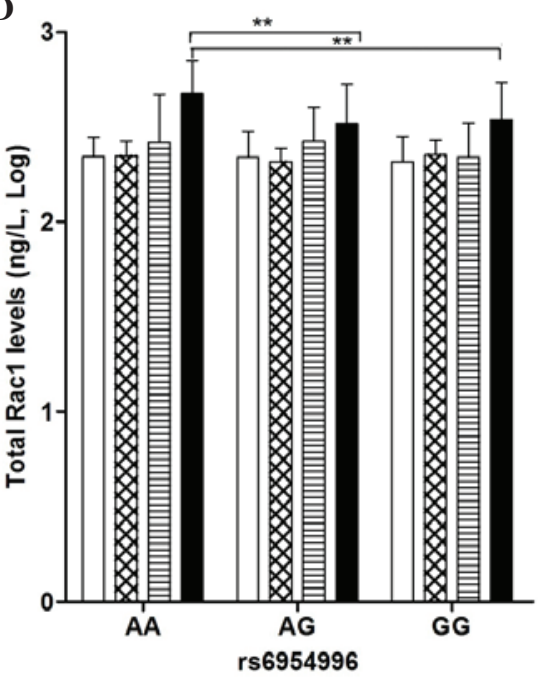

Figure 3. Association analysis of RAC1 genotypes with expression levels of total Rac1. (A) association analysis of rs702482 genotypes with levels of total Rac1; (B) association analysis of rs10951982 genotypes with levels of total Rac1; (C) association analysis of rs702483 genotypes with levels of total Rac1; (D) association analysis of rs6954996 genotypes with levels of total Rac1. For multiple comparisons, one-way analysis of variance following log-transformation, followed by Tukey's post-hoc test, was performed for each group. ${ }^{*} \mathrm{P}<0.05$ and ${ }^{* *} \mathrm{P}<0.01$. Rac1, Ras-related C3 botulinum toxin substrate 1 ; KT, kidney transplantation; LT, liver transplantation; HT, heart transplantation.

$(-2.09 \pm 0.38 ; \mathrm{P}<0.05)$ and AA genotype $(-2.16 \pm 0.33 ; \mathrm{P}<0.01)$ of rs702483, respectively.

Association between the RACl genotype and the levels of total Racl and Racl-GTP. The present study examined the association between the RACl genotype and the levels of total Rac1 in the study populations, which are listed in Fig. 3. Significant associations were found in rs702483 in the healthy control group, in which the level of total Rac1 was highest in the GG genotype $(2.70 \pm 0.25 \mathrm{ng} / \mathrm{l})$, compared with the AG genotype $(2.56 \pm 0.21 \mathrm{ng} / \mathrm{l})$ and AA genotype $(2.53 \pm 0.19 \mathrm{ng} / \mathrm{l})$, respectively $(\mathrm{P}<0.01)$. In rs6954996, the level of total Racl was highest in the AA genotype $(2.68 \pm 0.17 \mathrm{ng} / \mathrm{l})$, compared with the AG $(2.52 \pm 0.21 \mathrm{ng} / \mathrm{l})$ and GG genotype $(2.54 \pm 0.19 \mathrm{ng} / \mathrm{l})$, respectively $(\mathrm{P}<0.01)$. In the kidney transplant group, a significant difference was also apparent in rs702482, in which the level of total Rac1 was lowest in the AA genotype $(2.28 \pm 0.12 \mathrm{ng} / \mathrm{l})$, compared with the AT genotype $(2.35 \pm 0.13 \mathrm{ng} / \mathrm{l})$ and TT genotype $(2.33 \pm 0.13 \mathrm{ng} / \mathrm{l})$, respectively $(\mathrm{P}<0.05)$.
The association between the RACl genotype and the levels of Rac1-GTP in the study populations are listed in Fig. 4. As with the levels of total Rac1, significant associations were found in the healthy control group in rs702482, in which the level of Rac1-GTP was highest in the AT genotype $(2.36 \pm 0.22 \mathrm{ng} / \mathrm{l})$, compared with the AA genotype $(2.29 \pm 0.18 \mathrm{ng} / \mathrm{l})$ and TT genotype $(2.28 \pm 0.20 \mathrm{ng} / \mathrm{l})$, respectively $(\mathrm{P}<0.05)$. In rs10951982, the level of Rac1-GTP was lowest in the AA genotype $(2.23 \pm 0.16 \mathrm{ng} / \mathrm{l})$, compared with the AG genotype $(2.33 \pm 0.23 \mathrm{ng} / \mathrm{l})$ and $\mathrm{GG}$ genotype $(2.32 \pm 0.20 \mathrm{ng} / \mathrm{l})$, respectively $(\mathrm{P}<0.05)$.

\section{Discussion}

The present study was the first, to the best of our knowledge, to investigate and compare the mRNA expression levels of RAC1, and the protein levels of total Racl and Rac1-GTP in SOTRs and Chinese healthy subjects, and to determine the associations between $R A C l$ gene polymorphisms and the expression levels of $R A C 1$, Rac1 and Rac1-GTP. 


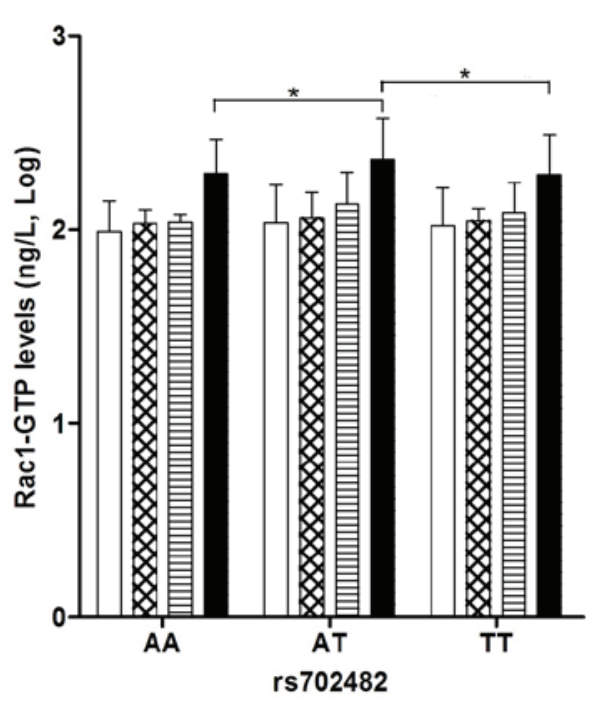

C

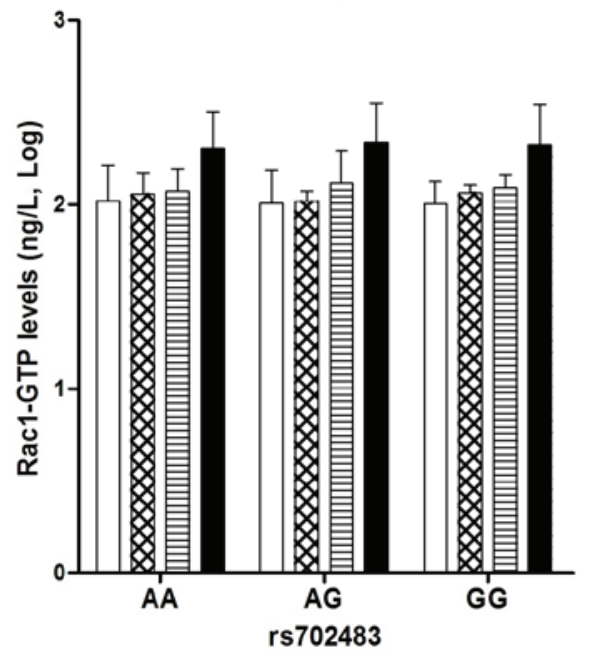

B

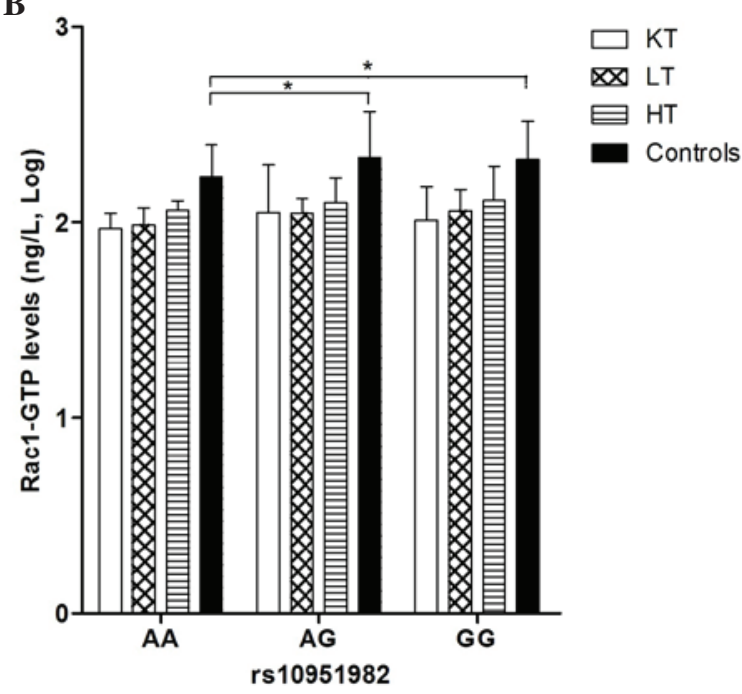

D

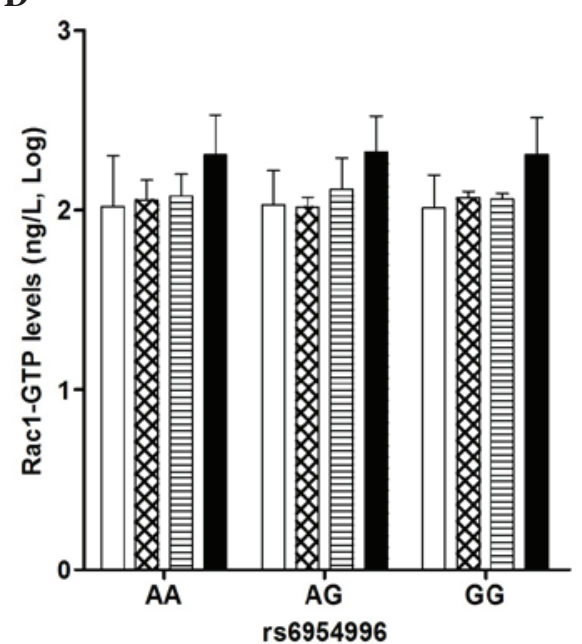

Figure 4. Association analysis of RAC1 genotypes with expression levels of Rac1-GTP. (A) Association analysis of rs702482 genotypes with levels of Rac1-GTP; (B) association analysis of rs10951982 genotypes with levels of Rac1-GTP; (C) association analysis of rs702483 genotypes with levels of Rac1-GTP; (D) association analysis of rs6954996 genotypes with levels of Rac1-GTP. For multiple comparisons, one-way analysis of variance following log-transformation, followed by Tukey's post-hoc test, was performed for each group. * $\mathrm{P}<0.05$. Rac1, Ras-related C3 botulinum toxin substrate 1; Rac1-GTP, Rac1-guanosine triphosphatase; KT, kidney transplantation; LT, liver transplantation; HT, heart transplantation.

The results of the present study, which consisted of 304 SOTRs comprising 164 kidney transplantations, 85 liver transplantations and 55 heart transplantations, and 332 healthy Hubei Chinese control subjects, demonstrated that the healthy population had higher levels of total Rac1 and Rac1-GTP, compared with the kidney, liver and heart transplant cases $(\mathrm{P}<0.001)$. It has been suggested that alterations of the $R A C l$ gene, through impairment of its activity, may affect susceptibility to diseases, including renal failure, cardiac failure and hypertension (34). It is known that activated Racl can increase cell proliferation and differentiation, and inhibiting cell apoptosis at the same time (4-11). It has been reported that $20 \%$ of tumors grow in Rac1-proficient mice, exhibiting overexpression of Rac1 in tumor tissue, compared with the surrounding normal tissue (27), which is in accordance with reports showing overexpression of Racl protein in different types of human tumor $(35,36)$. As Rac1-GTP protein is the active form of Rac1, increased expression of Rac1-GTP has been shown in the glomeruli of rats with podocyte-specific overexpression of the AT1 receptor, a model of effaced foot processes, podocyte depletion and FSGS $(28,29)$. Decreased expression of Rac1-GTP reduces the DEN-induced formation of liver tumors and affects the basal and DEN-induced expression of metabolic liver enzymes (27).

Extensive investigations have been performed to examine changes in the immune response gene expression profile in allograft recipients. It has been reported that these genes, involved in variant recognition, antigen-presenting synthesis, signal transduction, and the regulation of protein transcription and translation are downregulated following transplantation, including protein tyrosine phosphatase type IVA 1 (PTP4A1) (37) and potassium voltage-gated channel subfamily Q member 3 (KCNQ3) (38). As with other downregulated genes, the $R A C l$ gene is also involved in anti-apoptosis, signal transduction, and the regulation of cell cycle and proliferation. The present study demonstrated that the $R A C l$ gene was downregulated following organ transplantation, as observed for the PTP4Al and KCNQ3 genes. The changes 
in the immune response gene expression profile in allograft recipients are not only due to regulations of autoimmunity, but also occur in the use of exogenous immune inhibitors. Studies have shown that azathioprine exerts its immunosuppressive activity via the inhibition of Vav-mediated Racl activation, and consecutively suppresses the functions of Rac1 on T cell survival and T-cell-antigen-presenting cell conjugation $(39,40)$.

The present study further analyzed the expression levels of $R A C 1$ mRNA and its protein in different genotypes. For rs702482 in the healthy control group, the mRNA expression levels were lowest in the TT genotype $(-2.12 \pm 0.47)$, compared with AA $(-1.93 \pm 0.57)$ and AT $(-1.94 \pm 0.55)$, respectively $(\mathrm{P}<0.01)$, whereas the level of Rac1-GTP was highest in the AT genotype $(2.36 \pm 0.22 \mathrm{ng} / \mathrm{l})$, compared with the AA $(2.29 \pm 0.18 \mathrm{ng} / \mathrm{l})$ and TT genotypes $(2.28 \pm 0.20 \mathrm{ng} / \mathrm{l}) \mathrm{respec}-$ tively $(\mathrm{P}<0.05)$. For rs702483 in the healthy control group, the relative level of mRNA was lowest in the GG genotype $(-2.35 \pm 0.24)$, compared with the AA $(-2.00 \pm 0.53)$ and AG genotypes $(-1.98 \pm 0.55)$, respectively $(\mathrm{P}<0.01)$, whereas the level of total Rac1 was highest in the GG genotype $(2.70 \pm 0.25 \mathrm{ng} / \mathrm{l})$, compared with the AG $(2.56 \pm 0.21 \mathrm{ng} / \mathrm{l})$ and AA genotypes $(2.53 \pm 0.19 \mathrm{ng} / \mathrm{l})$, respectively $(\mathrm{P}<0.01)$. For rs6954996 in the healthy control group, the relative level of mRNA was highest in the GG genotype (-1.97 \pm 0.55$)$, compared with the AG $(-2.10 \pm 0.46)$ and AA genotype $(-2.26 \pm 0.41)$, respectively $(\mathrm{P}<0.05)$, whereas the level of total Rac1 was highest in the AA genotype (2.68 $\pm 0.17 \mathrm{ng} / \mathrm{l})$, compared with the AG $(2.52 \pm 0.21 \mathrm{ng} / \mathrm{l})$ and GG genotypes $(2.54 \pm 0.19 \mathrm{ng} / \mathrm{l})$, respectively, $(\mathrm{P}<0.01)$. The differences in the relative mRNA levels of $R A C 1$ in the genotypes were different from those of the proteins. It was difficult to determine the association between the mRNA levels of RACl and its protein. This may due to the complex regulatory mechanism of protein expression. In addition to mRNA, several factors can affect protein expression and activity, including ROS (41), shear stress (42), mechanical stretch (43), integrins (44), inflammatory cytokines (45), growth factors (46), homocysteine (47), high glucose concentrations $(48,49), \mathrm{NaCl}$ or osmotic stress (50-53), aldosterone (10,54) and angiotensin II (55-57).

In conclusion, the present study constitutes the first, to the best of our knowledge, to report that the expression levels of total Rac1 and Rac1-GTP were downregulated in SOTRs, and that the RACl genetic polymorphisms potentially affects the expression levels of RACl mRNA, and Rac1 and Rac1-GTP proteins. However, it is difficult to conclude the exact contribution of $R A C 1$ polymorphisms to the protein levels of Rac1 and Rac1-GTP due to the selection of SNPs and the limited number of subjects. Further gene functional investigations are urgently required to confirm and clarify these preliminary data. The present analyses provide a foundation for further functional investigations to reveal the biological and molecular functions of the RACl gene in solid organ transplantation.

\section{Acknowledgements}

This study was supported by National Natural Science Foundation of China (grant no. 81273591) and the Fundamental Research Funds for the Central Universities (China; grant no. 2014YGYL003). The funding bodies had no involvement in study design, data collection and analysis, decision to publish or preparation of the manuscript.

\section{References}

1. Rossman KL, Der CJ and Sondek J: GEF means go: Turning on RHO GTPases with guanine nucleotide-exchange factors. Nat Rev Mol Cell Biol 6: 167-180, 2005.

2. Park EJ, Ji KA, Jeon SB, Choi WH, Han IO, You HJ, Kim JH, Jou I and Joe EH: Rac1 contributes to maximal activation of STAT1 and STAT3 in IFN-gamma-stimulated rat astrocytes. JImmunol 173: 5697-5703, 2004.

3. Hoppe AD and Swanson JA: Cdc42, Rac1 and Rac2 display distinct patterns of activation during phagocytosis. Mol Biol Cell 15: 3509-3519, 2004.

4. Schmitz AA, Govek EE, Böttner B and Van Aelst L: Rho GTPases: Signaling, migration, and invasion. Exp Cell Res 261: $1-12,2000$.

5. Maroto B, Ye MB, von Lohneysen K, Schnelzer A and Knaus UG: P21-activated kinase is required for mitotic progression and regulates Plk1. Oncogene 27: 4900-4908, 2008.

6. Khosravi-Far R, Solski PA, Clark GJ, Kinch MS and Der CJ: Activation of Rac1, RhoA, and mitogen-activated protein kinases is required for Ras transformation. Mol Cell Biol 15: 6443-6453, 1995.

7. Wells CM, Walmsley M, Ooi S, Tybulewicz V and Ridley AJ: Rac1-deficient macrophages exhibit defects in cell spreading and membrane ruffling but not migration. J Cell Sci 117: 1259-1268, 2004.

8. Walmsley MJ, Ooi SK, Reynolds LF, Smith SH, Ruf S, Mathiot A, Vanes L, Williams DA, Cancro MP and Tybulewicz VL: Critical roles for Rac1 and Rac2 GTPases in B cell development and signaling. Science 302: 459-462, 2003.

9. Mizukawa B, Wei J, Shrestha M, Wunderlich M, Chou FS, Griesinger A, Harris CE, Kumar AR, Zheng Y, Williams DA and Mulloy JC: Inhibition of Rac GTPase signaling and downstream prosurvival $\mathrm{Bcl}-2$ proteins as combination targeted therapy in MLL-AF9 leukemia. Blood 118: 5235-5245, 2011.

10. Iwashima F, Yoshimoto T, Minami I, Sakurada M, Hirono Y and Hirata Y: Aldosterone induces superoxide generation via Rac1 activation in endothelial cells. Endocrinology 149: 1009-1014, 2008.

11. Ma Q, Cavallin LE, Yan B, Zhu S, Duran EM, Wang H, Hale LP, Dong C, Cesarman E, Mesri EA and Goldschmidt-Clermont PJ: Antitumorigenesis of antioxidants in a transgenic Racl model of Kaposi's sarcoma. Proc Natl Acad Sci USA 106: 8683-8688, 2009.

12. Canman CE and Kastan MB: Signal transduction. Three paths to stress relief. Nature 384: 213-214, 1996.

13. Jefferies CA and O'Neill LA: Racl regulates interleukin 1-induced nuclear factor kappaB activation in an inhibitory protein kappaBalpha-independent manner by enhancing the ability of the p65 subunit to transactivate gene expression. J Biol Chem 275: 3114-3120, 2000.

14. Ungefroren H, Groth S, Sebens S, Lehnert H, Gieseler F and Fändrich F: Differential roles of Smad2 and Smad3 in the regulation of TGF- $\beta 1$-mediated growth inhibition and cell migration in pancreatic ductal adenocarcinoma cells: Control by Rac1. Mol Cancer 10: 67, 2011.

15. Matos P, Skaug J, Marques B, Beck S, Veríssimo F, Gespach C, Boavida MG, Scherer SW and Jordan P: Small GTPase Rac1: Structure, localization, and expression of the human gene. Biochem Biophys Res Commun 277: 741-751, 2000.

16. Risch N and Merikangas KR: Linkage studies of psychiatric disorders. Eur Arch Psychiatry Clin Neurosci 243: 143-149, 1993.

17. Muise AM, Walters T, Xu W, Shen-Tu G, Guo CH, Fattouh R Lam GY, Wolters VM, Bennitz J, van Limbergen J, et al: Single nucleotide polymorphisms that increase expression of the guanosine triphosphatase RAC1 are associated with ulcerative colitis. Gastroenterology 141: 633-641, 2011.

18. Tapia-Castillo A, Carvajal CA, Campino C, Vecchiola A, Allende F, Solari S, García L, Lavanderos S, Valdivia C, Fuentes C, et al: Polymorphisms in the RAC1 gene are associated with hypertension risk factors in a Chilean pediatric population. Am J Hypertens 27: 299-307, 2014. 
19. Bourgine J, Garat A, Allorge D, Crunelle-Thibaut A, Lo-Guidice JM, Colombel JF, Broly F and Billaut-Laden I: Evidence for a functional genetic polymorphism of the Rho-GTPase Racl. Implication in azathioprine response? Pharmacogene Genomics 21: 313-324, 2011.

20. Derijks LJ and Wong DR: Pharmacogenetics of thiopurines in inflammatory bowel disease. Curr Pharm Des 16: 145-154, 2010.

21. Sahasranaman S, Howard D and Roy S: Clinical pharmacology and pharmacogenetics of thiopurines. Eur J Clin Pharmacol 64 753-767, 2008

22. Taher M, Ebrahimi Daryani N, Hedayat M, Eslamian M, Farhadi E, Mahmoudi M, Shirzad S, Nouri Taromlou MK, Chaharmahali M, Nicknam MH, et al: RAC1 single nucleotide polymorphisms in Crohn's disease. Clin Res Hepatol Gastroenterol 38: e75-e77, 2014.

23. Mundel P and Reiser J: Proteinuria: An enzymatic disease of the podocyte? Kidney Int 77: 571-580, 2010.

24. Welsh GI and Saleem MA: The podocyte cytoskeleton-key to a functioning glomerulus in health and disease. Nat Rev Nephrol 8: 14-21, 2011.

25. Brown JH, Del Re DP and Sussman MA: The Rac and Rho hall of fame: A decade of hypertrophic signaling hits. Circ Res 98: 730-742, 2006

26. Lezoualc'h F, Métrich M, Hmitou I, Duquesnes N and Morel E: Small GTP-binding proteins and their regulators in cardiac hypertrophy. J Mol Cell Cardiol 44: 623-632, 2008.

27. Bopp A, Wartlick F, Henninger C, Schwarz M, Kaina B and Fritz G: Rac1 promotes diethylnitrosamine (DEN)-induced formation of liver tumors. Carcinogenesis 36: 378-389, 2015.

28. Hoffmann S, Podlich D, Hähnel B, Kriz W and Gretz N: Angiotensin II type 1 receptor overexpression in podocytes induces glomerulosclerosis in transgenic rats. J Am Soc Nephrol 15: 1475-1487, 2004.

29. Hsu HH, Hoffmann S, Endlich N, Velic A, Schwab A, Weide T, Schlatter E and Pavenstädt H: Mechanisms of angiotensin II signaling on cytoskeleton of podocytes. J Mol Med (Berl) 86 : 1379-1394, 2008

30. Nagase M: Role of Rac1 GTPase in salt-sensitive hypertension. Curr Opin Nephrol Hypertens 22: 148-155, 2013.

31. Shibata S, Mu S, Kawarazaki H, Muraoka K, Ishizawa K, Yoshida S, Kawarazaki W, Takeuchi M, Ayuzawa N, Miyoshi J, et al: Rac1 GTPase in rodent kidneys is essential for salt-sensitive hypertension via a mineralocorticoid receptor-dependent pathway. J Clin Invest 121: 3233-3243, 2011.

32. Liu YN, Zhou JL, Yang CX, Sheng RF, Luo XM, Zhang Yu and Shi SJ: Distribution of Racl gene polymorphism in Hubei Hans renal transplant patients of China. Chin Pharm J 49: 1923-1927, 2014.

33. Zhou JL, Liu YN, Sheng RF, Yang CX, Luo XM, Zhang Yu and Shi SJ: Analysis of RAC1 gene polymorphism in Hubei Chinese healthy population. Chin J Immunol 30: 1297-1301, 2014.

34. Nagase M and Fujita T: Role of Rac1-mineralocorticoid-receptor signalling in renal and cardiac disease. Nat Rev Nephrol 9: 86-98, 2013

35. Schnelzer A, Prechtel D, Knaus U, Dehne K, Gerhard M, Graeff H, Harbeck N, Schmitt M and Lengyel E: Rac1 in human breast cancer: Overexpression, mutation analysis, and characterization of a new isoform, Rac1b. Oncogene 19: 3013-3020, 2000.

36. Fritz G, Just I and Kaina B: Rho GTPases are over-expressed in human tumors. Int J Cancer 81: 682-687, 1999.

37. Stegall MD, Park WD, Kim DY, Covarrubias M, Khair A and Kremers WK: Changes in intragraft gene expression secondary to ischemia reperfusion after cardiac transplantation. Transplantation 74: 924-930, 2002.

38. Shah K, Tom Blake J, Huang C, Fischer P and Koo GC Immunosuppressive effects of a Kv1.3 inhibitor. Cell Immunol 221: 100-106, 2003.

39. Tiede I, Fritz G, Strand S, Poppe D, Dvorsky R, Strand D, Lehr HA, Wirtz S, Becker C, Atreya R, et al: CD28-dependent Rac1 activation is the molecular target of azathioprine in primary human CD4+ T lymphocytes. J Clin Invest 111: $1133-1145,2003$.
40. Poppe D, Tiede I, Fritz G, Becker C, Bartsch B, Wirtz S, Strand D, Tanaka S, Galle PR, Bustelo XR and Neurath MF: Azathioprine suppresses ezrin-radixin-moesin-dependent $\mathrm{T}$ cell-APC conjugation through inhibition of Vav guanosine exchange activity on Rac proteins. J Immunol 176: 640-651, 2006.

41. Nagase M, Ayuzawa N, Kawarazaki W, Ishizawa K, Ueda K, Yoshida S and Fujita T: Oxidative stress causes mineralocorticoid receptor activation in rat cardiomyocytes: Role of small GTPase Rac1. Hypertension 59: 500-506, 2012.

42. Tzima E, Del Pozo MA, Kiosses WB, Mohamed SA, Li S, Chien S and Schwartz MA: Activation of Racl by shear stress in endothelial cells mediates both cytoskeletal reorganization and effects on gene expression. EMBO J 21: 6791-6800, 2002.

43. Aikawa R, Nagai T, Tanaka M, Zou Y, Ishihara T, Takano H, Hasegawa H, Akazawa H, Mizukami M, Nagai R and Komuro I: Reactive oxygen species in mechanical stress-induced cardiac hypertrophy. Biochem Biophys Res Commun 289: 901-907, 2001.

44. Price LS, Leng J, Schwartz MA and Bokoch GM: Activation of Rac and Cdc42 by integrins mediates cell spreading. Mol Biol Cell 9: 1863-1871, 1998.

45. Papaharalambus C, Sajjad W, Syed A, Zhang C, Bergo MO, Alexander RW and Ahmad M: Tumor necrosis factor alpha stimulation of Racl activity. Role of isoprenylcysteine carboxylmethyltransferase. J Biol Chem 280: 18790-18796, 2005.

46. Kurokawa K, Itoh RE, Yoshizaki H, Nakamura YO and Matsuda M: Coactivation of Rac1 and Cdc42 at lamellipodia and membrane ruffles induced by epidermal growth factor. Mol Biol Cell 15: 1003-1010, 2004.

47. Yi F, Zhang AY, Janscha JL, Li PL and Zou AP: Homocysteine activates NADH/NADPH oxidase through ceramide-stimulated Rac GTPase activity in rat mesangial cells. Kidney Int 66: 1977-1987, 2004

48. Lin CL, Wang JY, Ko JY, Surendran K, Huang YT, Kuo YH and Wang FS: Superoxide destabilization of beta-catenin augments apoptosis of high-glucose-stressed mesangial cells. Endocrinology 149: 2934-2942, 2008.

49. Shen E, Li Y, Li Y, Shan L, Zhu H, Feng Q, Arnold JM and Peng T: Racl is required for cardiomyocyte apoptosis during hyperglycemia. Diabetes 58: 2386-2395, 2009.

50. Uhlik MT, Abell AN, Johnson NL, Sun W, Cuevas BD, Lobel-Rice KE, Horne EA, Dell'Acqua ML and Johnson GL: Rac-MEKK3-MKK3 scaffolding for p38 MAPK activation during hyperosmotic shock. Nat Cell Biol 5: 1104-1110, 2003.

51. Friis MB, Friborg CR, Schneider L, Nielsen MB, Lambert IH, Christensen ST and Hoffmann EK: Cell shrinkage as a signal to apoptosis in NIH 3T3 fibroblasts. J Physiol 567: 427-443, 2005.

52. Silva GB and Garvin JL: Racl mediates NaCl-induced superoxide generation in the thick ascending limb. Am J Physiol Renal Physiol 298: F421-F425, 2010.

53. Liu R and Juncos LA: GTPase-Rac enhances depolarization-induced superoxide production by the macula densa during tubuloglomerular feedback. Am J Physiol Regul Integr Comp Physiol 298: R453-R458, 2010.

54. Shibata S, Nagase M, Yoshida S, Kawachi H and Fujita T: Podocyte as the target for aldosterone: Roles of oxidative stress and Sgk1. Hypertension 49: 355-364, 2007.

55. Schmitz U, Thömmes K, Beier I, Wagner W, Sachinidis A, Düsing R and Vetter H: Angiotensin II-induced stimulation of p21-activated kinase and c-Jun NH2-terminal kinase is mediated by Racl and Nck. J Biol Chem 276: 22003-22010, 2001.

56. Takemoto $M$, Node K, Nakagami H, Liao Y, Grimm M, Takemoto Y, Kitakaze M and Liao JK: Statins as antioxidant therapy for preventing cardiac myocyte hypertrophy. J Clin Invest 108: 1429-1437, 2001.

57. Nishida M, Tanabe S, Maruyama Y, Mangmool S, Urayama K, Nagamatsu Y, Takagahara S, Turner JH, Kozasa T, Kobayashi H, et al: G alpha 12/13- and reactive oxygen species-dependent activation of c-Jun NH2-terminal kinase and p38 mitogen-activated protein kinase by angiotensin receptor stimulation in rat neonatal cardiomyocytes. J Biol Chem 280: 18434-18441, 2005. 